\title{
THE IMPACT OF INTERNATIONAL ENERGY PRICES ON WORLD TRADE: PANEL EVIDENCE OF GRAVITY MODELS FOR SELECTED COUNTRIES ${ }^{1,2}$
}

\author{
Kafkas University \\ Economics and Administrative \\ Sciences Faculty \\ KAUJEASF \\ Vol. 12, Issue 24, 2021 \\ ISSN: $1309-4289$ \\ Article Submission Date: 06.07.2021 \\ Accepted Date: 09.10.2021 \\ E - ISSN: 2149-9136
}

\section{Memduh Alper DEMİR \\ Dr. \\ Kastamonu University Faculty of Economics and Administrative Sciences, Kastamonu, Turkey mademir@kastamonu.edu.tr} ORCID ID: 0000-0002-9926-2611

\section{Utku UTKULU \\ Prof. Dr.}

Dokuz Eylül University

Faculty of Economics and Administrative Sciences İzmir, Turkey utku.utkulu@deu.edu.tr ORCID ID: 0000-0002-8419-0598

\section{ABSTRACTI The aim of this} article is to examine the impacts of prices of energy and non-energy goods on world trade by including some variables that affect trade for selected countries within the framework of relative prices. The relevant literature confirms that the bilateral trade is theoretically analyzed by using the gravity models. The theoretical gravity models can be empirically applied by using the various panel regression techniques. In this study, three types of panel regression techniques are employed to define the effects of independent variables in the case of trade as the dependent variable. These are Stochastic Frontier, Random Effects, and Fixed Effects Filtered Estimator techniques. According to our panel regression findings, the price increases in the index of energy goods have negative effects on the exports, resulting in the terms of trade being against the countries in this case. Findings suggest that socio- economic policies preventing energy prices from rising need to be developed. Raising the supply to meet the increasing demand could be one of the major policies. Considering the other variables in the model, empirical evidence suggests that world trade volume can be increased not only by strengthening growth policies, ensuring competitiveness in the market, and providing effective logistics management but also by ensuring cultural cooperation, developing business partnerships among the similar income-level countries, and increasing and/or diversifying energy supply.

Keywords: World trade, energy prices, gravity models of bilateral trade, panel random effects, fixed effects filtered and stochastic frontier estimation methods

Jel codes: F12, F14, Q40

\section{Scope: Economics}

Type: Research

DOI: 10.36543/kauiibfd.2021.039

Cite this Paper: Demir, M. A. \& Utkulu, U. (2021). The impact of international energy prices on world trade: panel evidence of gravity models for selected countries. KAUJEASF, 12(24), 946974.

\footnotetext{
${ }^{1}$ This article was derived from the PhD Thesis of "The Effects of International Energy Prices on the World Trade", which was accepted at the Graduate School of Social Sciences, Department of Economics, Dokuz Eylül University, İzmir.

${ }^{2}$ It is confirmed that the relevant ethical rules are followed in the study.
} 


\section{ULUSLARARASI ENERJI \\ FIYATLARININ DÜNYA TICARETİ \\ ÜZERİNE ETKISİ: SEÇILMIŞ \\ ÜLKELER İÇİN ÇEKIM MODELLERININ PANEL BULGULARI}

\author{
Makale Gönderim Tarihi: 06.07.2021 \\ Memduh Alper DEMIR \\ Dr. \\ Kastamonu Üniversitesi \\ İktisadi ve İdari Bilimler Fakültesi, \\ Kastamonu, Türkiye \\ mademir@kastamonu.edu.tr \\ ORCID ID: 0000-0002-9926-2611
}

\section{Utku UTKULU}

Prof. Dr.

Dokuz Eylül Üniversitesi

İktisadi ve İdari Bilimler Fakültesi,

İzmir, Türkiye

utku.utkulu@deu.edu.tr

ORCID ID: 0000-0002-8419-0598

Yayına Kabul Tarihi: 09.10.2021

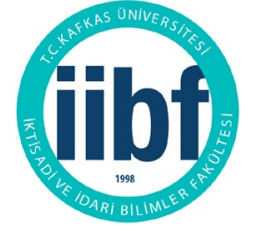

Kafkas Üniversitesi İktisadi ve İdari Bilimle Fakültesi KAÜIIBBFD

Cilt, 12, Say1 24, 2021

ISSN: $1309-4289$

E - ISSN: 2149-9136
ÖZI enerji dışı malların fiyatlarının, nispi fiyatlar çerçevesinde ve ticareti etkileyen diğer bazı değişkenler de ilave edilerek, dünya ticareti üzerindeki etkisini seçilmiş ülkeler için incelemektir. İlgili literatür, iki yönlü ticaretin çekim modelleri kullanılarak teorik olarak analiz edildiğini ortaya koymaktadır. Teorik çekim modeli analizi ampirik olarak çeşitli panel regresyon teknikleri ile uygulanabilmektedir. Araştırmada, bağımsız değişkenlerin bağımlı değişken olan ticaret üzerindeki etkisini belirlemede üç tür panel regresyon tekniğ kullanılmıștır. Bunlar, stokastik sınır, rassal etkiler ve filtrelenen sabit etkiler tahmincisi teknikleridir. Elde edilen panel regresyon bulguları, enerji malları fiyat endeksindeki artışın ihracat üzerinde negatif etkide bulunduğunu, bu durumda da diş ticaret hadlerinin ilgili ülkelerin aleyhine olduğunu göstermektedir. Bulgular, enerji fiyatlarının yükselmesini engelleyecek sosyo-ekonomik politikalar geliştirilmesi gerektiğine işaret etmektedir. Artan talebi karşılamak için arzı arttırmak, temel politikalardan birisi olabilir. Modeldeki diğer değişkenler dikkate alındığında, elde edilen ampirik bulgular, büyüme yönlü politikaların arttırılması, piyasalarda rekabetçiliğin sağlanması ve etkili lojistik yönetiminin gerçekleștirilmesinin yanı sıra kültürel is birliğinin sağlanması, benzer gelir seviyesindeki ülkelerin iş ortaklıklarının geliştirilmesi, enerji arzının arttırılması ve/veya çeşitlendirilmesi ile dünya ticaret hacminin artırılabileceğini göstermektedir.

Anahtar Kelimeler: Dünya ticareti, enerji fiyatlarl, iki-yönlü ticaretin çekim modelleri, rassal etkiler, filtrelenen sabit etkiler ve stokastik sinır tahmin yöntemleri.

JEL Kodu: F12, F14, Q40

Alan: İktisat

Türü: Araştırma 


\section{INTRODUCTION}

Since the beginning of the industrial revolution, energy has become increasingly important both as an input on production lines and for household use. A large part of the energy resources used are obtained from fossil fuels like oil, natural gas, and coal. Thus, the change in the prices of energy resources has resulted in the change in demand for these goods. It is obvious that the countries which demand energy goods are the countries that produce non- energy goods intensively. It is also observed that these countries export non-energy goods to countries exporting energy goods.

Energy products have gained importance since the middle of the 19th century. Energy goods are traded; the countries that produce non-energy goods need these energy products for their manufacturing industries, and the less developed or developing countries that export energy goods are seen as markets for their non-energy goods. This cycle has continued throughout the 20th century.

Under open economy conditions, surplus of a good is exported after domestic consumption, and if the product is not in sufficient quantities, it is imported. Energy goods are also traded. Four special cases emerge in the international or regional trade of energy products which are self-sufficient in energy; importing to reinforce its internal resources; exporting and finally, importing country without domestic resources. Energy goods are generally used as raw materials (or primary goods) rather than their intended use as final products. In the context of primary goods versus final goods, there are two directions in the world trade. While the direction of primary goods runs from south to north, there exits trade in final products from north to south, i.e. interindustry trade. Therefore, the primary goods-based energy goods market is also related to the north-south trade issue in the trade literature. When the north-south direction of world trade and the sanction power of countries in the regulation of this type of trade are concerned, the country which consumes the primary product instead of producing it, becomes an effective party in this trade. The demand for energy goods is determined by the production and consumption capacities of countries that produce final products.

Since Alfred Marshall, foreign trade literature has been developed within the framework of bilateral demands of the countries. In the literature of energy economics, the effects of energy prices on production, consumption, and some internal macroeconomic variables (GDP, GDP Growth and etc.) are examined. However, the effect of energy prices on trade on a global scale has not been studied in detail. In this context, this article examines the effects of international energy prices on world trade. In specific, bilateral demand between energyexporting countries and non-energy goods-exporting countries are taken in to 
account. Thus, the advantages and disadvantages arising from foreign trade are revealed, and the effects of changes in energy prices on international trade depending on price and income elasticities are also analyzed. In this study, the effect of energy prices and prices of non-energy goods on world trade within the framework of relative prices is examined for selected countries. In addition, some other variables that affect trade are also included in the analysis.

In this paper, the effect of the relative prices and other variables such as gross domestic products (GDP), populations, common language, contiguity, and common colonizer are theoretically modeled using the gravity models. Empirically, these parameters are analyzed by various panel regression methods, namely, Fixed Effect Filter, Stochastic Frontier, and Panel Random-effect estimations. The rest of the article is structured as follows: The following second chapter summarizes literature; the third chapter contains the theoretical background that reveals an empirically computable gravity model which derived from the theoretical gravity model, and the fourth chapter includes the data set. The fifth chapter gives the econometric methodology, while the sixth chapter presents empirical results. The last chapter gives a discussion of inferences from the findings, some conclusions and policy implications.

\section{LITERATURE REVIEW}

In the literature, there are very few studies exploring the relation between energy prices and bilateral trade, especially from the world trade perspective. On the other hand, the relevant literature confirms that existing studies are not based on relative price elasticity and do not examine its effects on world trade. In the literature, there are also studies including the dimension of time series with a single country regarding the relationship between the foreign trade and energy prices (generally oil prices). However, the existing literature examines the relationship between gross domestic product or other macroeconomic variables and energy prices from the current account balance perspective.

Some studies have included bilateral trade on a country basis and examined the relationship between energy prices and international trade on a country scale but not on a global scale. It is noteworthy that the energy prices of all fossil fuels are not considered in the analysis in the existing literature. Instead, it is only used the impact of oil prices on explaining trade. In terms of the relative price, the effect of energy goods' prices and non-energy goods' prices on trade has not been studied so far. In particular, the studies of Chen and Hsu (2013), Sato and Dechezleprete (2015), and Rafiq, Sgro, and Apergis (2016) do not take the prices of all energy products into account, but they are the closest to the subject. These studies generally consider the impact of oil prices on bilateral 
trade. They also do not separate countries as producers of energy goods and nonenergy goods and examine the bilateral relations between them.

Chen and Hsu (2013) studied the effect of oil price volatility on bilateral trade for a data set consisting of 117 countries by converting the daily oil price series into an annual volatility data set. The effect of volatility in oil prices on bilateral trade was found negative. Sato and Dechezleprete (2015) created a data set with 16 years of observations in 62 manufacturing industry sectors in 42 countries. In the analysis, they analyzed the effect of price series created by the difference in industry-based real industrial energy prices of the two countries on bilateral trade. $10 \%$ increase in energy price differences in the sectors of the two countries increased imports by $0.2 \%$. In their study for the period 1981-2013, Rafiq, Sgro, and Apergis (2016) found that the increase in petroleum prices positively affected the petroleum trade balance of petroleum-exporting countries. However, increases in petroleum prices negatively affected the trade balance of petroleum-importing countries. In this study, the trade balance was examined under the bilateral concept. The model also included positive and negative oil shocks.

In addition, studies that indirectly examine the relationship between energy price and world trade or examine some of relations between energy prices and other trade variables such as trade deficit or current account balance are included in Appendix 1.

In conclusion, there are some main issues that distinguish this study in hand from other studies which remarks its possible contributions to the existing literature. These are the following issues: There exits is no study, to our best knowledge, which includes the prices of energy goods and non-energy goods together in the form of relative prices. In the relevant empirical literature, only oil prices are considered as the price of energy goods. The price index of the energy goods used in this study is obtained by combining basic fossil fuels, natural gas, oil, and coal. However, the effect of the distance is considered as an indicator that expresses transportation costs like other gravity models in the existing literature. Furthermore, the Baltic Index, an alternative transportation cost indicator, is used simultaneously in the analysis. While the distance variable is time-invariant, the Baltic Index shows a structure that is time-varying. Thus, the effect of the transportation cost indicator in two different structures are measured. Finally, another point that distinguishes this study from others in the literature is the use of a technique based on the econometric method, that is, the fixed effect filter estimation method used in bilateral gravity models. 


\section{TRANSITION FROM THEORETICAL GRAVITY MODEL TO EMPIRICALLY COMPUTABLE ONE}

In this study, the gravity theoretical model is employed. Gravity models are built on bilateral trade. Bilateral trade is defined as mutual trade between two countries. In other words, it is the whole of export movements from country A to country B, and vice versa. Analysis of measures promoting trade and investment between the two countries has become easier through bilateral analysis. In this context, by employing these measures, trade barriers such as customs tariffs, import quotas, and export restrictions, etc. between the two countries can be reduced. In addition, the effect of variables such as contiguity, distance, and common culture between the two countries can also be examined in bilateral trade as well. The bilateral trade analysis also allows the inclusion of income and price effects on trade between the two countries. Gravity models are also derived from the bilateral trade concept. They indicate that trade between the two countries essentially varies depending on their distance and economic sizes.

Assuming that the world markets operate by imperfect competition dynamics, and the structure of energy goods is particularly homogeneous, the theoretical and empirical models applied in this paper are the Krugman-type gravity models (like Bergstrand et.al., 2013) based on the assumptions of homogeneous firm and imperfect competition. While Allen and Arkolakis (2016) theoretically expresses the Krugman's gravity model, Bergstrand (1989) and Anderson and van Wincoop (2003) transform the theoretical gravity model to the empirical form based on monopolistic competition. These three studies are the basic reference sources used in creating the computable empirical gravity model of this study.

Krugman's theoretical gravity model (Equation 1) can be expressed as follows (Allen and Arkolakis, 2016: p.23-29):

$$
\begin{gathered}
X_{i j}=X_{j} P_{j}^{\sigma-1}\left(\frac{\sigma}{\sigma-1} \frac{\omega_{i}}{z_{i}} \tau_{i j}\right)^{1-\sigma} d \omega \Leftrightarrow \\
X_{i j}=\left(\frac{\sigma}{\sigma-1}\right)^{1-\sigma} \tau_{i j}^{1-\sigma}\left(\frac{\omega_{i}}{z_{i}}\right)^{1-\sigma} N_{i} X_{j} P_{j}^{\sigma-1}
\end{gathered}
$$

where $X_{i j}$ is the export value from country $\mathrm{i}$ to country $\mathrm{j}, \tau_{i j}^{1-\sigma}$ is the trade cost between two countries, $z_{i}$ is the country i's common productivity in all firms, $\omega_{i}$ is the variety of goods in country $\mathrm{i}, N_{i}$ is the measure of firms producing in country $\mathrm{i}, X_{j}$ is the amount of imported goods in country $\mathrm{j}$, which is the opposite country, $P_{j}^{\sigma-1}$ is the general level of prices (price index) in country $\mathrm{j}$ (in other words, it reflects the costs in the importing country), $\sigma$ is the elasticity value, and $X_{j} P_{j}^{\sigma-1}$ this multiplication, in a sense, shows the income of country $\mathrm{j}$. 
In addition, Anderson and van Wincoop (2003:p. 174-175) reported a simple gravity equation obtained from the general equilibrium model under the assumption of constant substitution elasticity in the following equation 2 :

$$
T_{i j}=Y_{i} E_{j}\left(\frac{t_{i j}}{\Pi_{i} P_{j}}\right)^{1-\sigma}
$$

where $T_{i j}$ is the trade value between country $\mathrm{i}$ and $\mathrm{j}, Y_{i}$ is the total output of country i, $E_{j}$ is country j's expenditures, in other words, country j's income, $t_{i j}$ is the trade costs between two countries, $\Pi_{i}$ and $P_{j}$ are price indexes of country $\mathrm{i}$ and $\mathrm{j}$.

In terms of this logic, consumers maximize their welfare by consuming the country's produced A and unproduced B goods with minimum amount, subjecting to budget constraints. The budget constraints depend not only on the amount of goods produced, but also on the well-regulated exchange rate and customs tax rate and the nominal income of the country. Technology is the same among firms; these firms use capital and labor as inputs. All nation has a constant capital and labor supplies. Given the constant flexibility of the transformation function, firms try to maximize their profits and sell some of their products to the external markets. This means companies manufacture with increasing returns to scale in the first phase and export to international markets with reduced returns to scale due to shipping costs in the second stage. The export function of the goods produced by the firms aiming at profit maximization is (see Starck, 2012:p. 14):

$$
P X_{i j}=\alpha_{0} Y_{i}^{\alpha_{1}}\left(\frac{K_{i}}{L_{i}}\right)^{\alpha_{2}} Y_{j}^{\alpha_{3}}\left(\frac{Y_{j}}{L_{j}}\right)^{\alpha_{4}} C_{i j}^{\alpha_{5}} T_{i j}^{\alpha_{6}} E_{i j}^{\alpha_{7}} P_{i}^{\alpha_{8}} P_{j}^{\alpha_{9}} U_{i j}
$$

In Equation 3, the nominal export value $P X_{i j}$ is based on the exporter's and importer's GDP $\left(\mathrm{Y}_{\mathrm{i}}\right.$ and $\left.\mathrm{Y}_{\mathrm{j}}\right)$, the capital-labour rate of country $i\left(\frac{K_{i}}{L_{i}}\right)$, the per capita income of the importing country $j\left(\frac{Y_{j}}{L_{j}}\right)$ and $C_{i j}$ transportation costs and $T_{i j}$ as tariff rates, $E_{i j}$ is exchange rates, $\mathrm{P}_{\mathrm{i}}$ and $\mathrm{P}_{\mathrm{j}}$ are the exporting and importing country's prices, respectively. Bergstrand (1989) introduced a slightly more simplified version of Equation 3 with increasing returns to scale. Bergstrand (1989) carried out a study based on monopolistic competition and adapted to gravity modeling, considering the relationships with differentiated goods and economies of scale. Bergstrand's equation is:

$$
P X_{i j}=\alpha_{0} Y_{i}^{\alpha_{1}}\left(\frac{Y_{i}}{L_{i}}\right)^{\alpha_{2}} Y_{j}^{\alpha_{3}}\left(\frac{Y_{j}}{L_{j}}\right)^{\alpha_{4}} D_{i j}^{\alpha_{5}} A_{i j}^{\alpha_{6}} U_{i j}
$$


where $P X_{i j}$ shows the value of exports from country $\mathrm{i}$ to country $\mathrm{j}, \mathrm{Y}_{\mathrm{i}}$ and $\mathrm{Y}_{\mathrm{j}}$ show countries' gross domestic products, $\mathrm{L}_{\mathrm{i}}$ and $\mathrm{L}_{\mathrm{j}}$ are countries' populations, and $\mathrm{D}_{\mathrm{ij}}$ is the distance between countries. Other factors that may affect trade flow is Aij, and finally $U_{i j}$ is the error term.

When equations 3 and 4 are compared, it is clear that the capital /labor rate variable for country i can be considered as the per capita income of country $i$, and transportation costs are used instead of the distance variable in Equation 4. Also, $T_{i j}, E_{i j}, \mathrm{P}_{\mathrm{i}}$ and $\mathrm{P}_{\mathrm{j}}$ variables in Equation 3 are used instead of the $\mathrm{A}_{\mathrm{ij}}$ variable in Equation 4 (Starck, 2012:14). In this framework, the empirical model of the study in hand is created with the use of some assumptions. Considered assumptions for the empirical model created are goods A (energy goods) and B (non-energy goods) and single price (not $\mathrm{P}_{\mathrm{i}}$ exporter and $\mathrm{P}_{\mathrm{j}}$ importer) $\mathrm{P}_{\text {world. }}$ The template of the model created by considering the theoretical background is shown in Table 1.

Table 1: Transition from the Theoretical Model to the Empirical One

\begin{tabular}{|c|c|}
\hline $\begin{array}{l}\text { Theoretical Model Variable } \\
\text { (Considered Krugman, Anderson and Van Wincopp, } \\
\text { Bergstrand) }\end{array}$ & Empirical Model Indicator \\
\hline$X_{i j}$ & $\operatorname{lnEXPORT_{ij}}$ \\
\hline $\begin{array}{l}\text { The variables } \mathrm{Y}_{\mathrm{i}} \text { and } \mathrm{Y}_{\mathrm{j}} \text { appear hidden in the analysis of the } \\
\text { Krugman model. Under the assumption that each firm } \\
\text { produces one product, } \frac{\omega_{i}}{z_{i}} \text { is the productivity per firm. When } \\
\text { this value multiply with } N_{i} \text { (number of firms in the country) } \\
\text { results in } \mathrm{Y}_{\mathrm{i}} \text { that is output of country } \mathrm{i} \text {, in other words country } \\
\text { i's income. In the opposite country, the variable } X_{j} P_{j}^{\sigma-1} \text { gives } \\
Y_{\mathrm{j}} \text {. }\end{array}$ & $\ln G D P_{i}$ and $\ln G D P_{j}$ \\
\hline $\begin{array}{l}\Pi_{i} \text { and } P_{j} \text { terms are price indices in country } \mathrm{i} \text { and country } \mathrm{j} \text {, } \\
\text { respectively. }\end{array}$ & $\begin{array}{l}\text { LnP } \\
\text { Here, the prices of non-energy } \\
\text { goods and energy goods were } \\
\text { taken by proportioning each } \\
\text { other. }\end{array}$ \\
\hline $\mathrm{L}_{\mathrm{i}}$ and $\mathrm{L}_{\mathrm{j}}$ & $\ln P O P_{i}$ and $\ln P O P_{j}$ \\
\hline$\left(\frac{Y_{i}}{L_{i}}\right.$ and $\left.\frac{Y_{j}}{L_{j}}\right)$ & $\begin{array}{l}\text { These are per capita income. In } \\
\text { the study, the differences } \\
\text { between per capita income } \\
\text { variables were taken. The reason } \\
\text { for this is that if } \ln D G D P P C_{i j} \text { is } \\
\text { close to each other, countries } \\
\text { will trade more. }\end{array}$ \\
\hline $\mathrm{D}_{\mathrm{ij}}$ and even $\tau_{i j}^{1-\sigma}$ & In terms of transportation costs \\
\hline
\end{tabular}




\begin{tabular}{|c|c|}
\hline $\begin{array}{l}\text { Theoretical Model Variable } \\
\text { (Considered Krugman, Anderson and Van Wincopp, } \\
\text { Bergstrand) }\end{array}$ & Empirical Model Indicator \\
\hline & 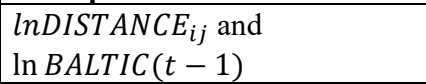 \\
\hline$\tau_{i j}^{1-\sigma}$ and $\mathrm{A}_{\mathrm{ij}}$ & $\begin{array}{l}\text { All factors that make trade } \\
\text { difficult or facilitating, which are } \\
\text { called iceberg trade costs } \\
\text { between the two countries, can } \\
\text { be included. Common official } \\
\text { and ethnic language, colonial } \\
\text { connection, etc. }\end{array}$ \\
\hline
\end{tabular}

Source: Prepared by Authors.

In this context, the revised regression model is expressed as follows (equation 5):

$$
\begin{aligned}
\operatorname{lnEXPORT}_{i j}= & a_{0}+a_{1} \operatorname{lnGDP}_{i}+a_{2} \operatorname{lnGDP_{j}}+a_{3} \operatorname{lnPOP_{i}}+a_{4} \operatorname{lnPOP} P_{j} \\
& +a_{5} \operatorname{lnDI} \operatorname{STANCE}_{i j}+a_{6} \operatorname{lnP}+a_{7} \ln \text { BALTIC }(t-1) \\
& +a_{8} \ln \text { DGDPPC }_{i j}+a_{9} \text { CONTIGUITY }_{i j} \\
& +a_{10} \text { COMMON OFFICIAL LANGUAGE }_{i j} \\
& +a_{11} \text { COMMON ETHNIC LANGUAGE }_{i j} \\
& +a_{12} \text { COLONY }_{i j}+a_{13} \text { COMCOL }_{i j}+a_{14} \text { COL }_{i j} \\
& + \text { error term }
\end{aligned}
$$

\section{ECONOMETRIC METHODOLOGY}

The empirical model used here is based on the gravity model explained in the earlier section. As regards the empirical model, that is equation 5, variables are analyzed by utilizing three different methods, namely stochastic frontier, filtered fixed-effects, and panel random effects panel estimation methods, and the results are compared. Using three different methods enables us to see how consistent and robust the estimation results are.

\subsection{Panel Random Effects Estimation Method}

There are two different types of classical panel models, namely, fixed effect and random effect models. The main aim of the fixed effects panel data analysis is to compare groups (such as male/female), but not individuals. The fixed effects panel data analysis considers the connection among dependent variables and an independent variable in an entity. This entity can be a person, company, or country and affects common variables (Anna et.al., 2014:p. 233).

Unlike the fixed effects model, in the random effects model, it is assumed that there is a random variation between entities and unrelated to the independent 
variables in the model. The basic difference between the fixed effects model and the random effects model is that the neglected variables are not related to the independent variables in the random effects model. However, the neglected variables are concerned to the independent variables in the fixed effects model (Greene, 2008:p. 183).

The random effects model enables model parameters to vary from one entity to another. Hence it provides heterogeneity between individuals. If variations between entities have such effects on the dependent variable, the concept of random effects is used. Unlike the fixed effects model, the random effects model gives the errors between entities and within an entity (Wooldridge, 2016:p. 441-442).

One of the major features of panel data analysis is that it provides unobservable variables to be controlled and to account for the heterogeneity at the entity level. In the study, a particular country pair is selected as an entity. Initially, the Hausman test can be used to determine whether a fixed or random effect model would be appropriate for the data set. Our data set contains some time-invariant variables like distance and binary variables such as common language, common colonizer, and contiguity. For some individuals within the panel, these variables are unique and should be associated with other features. It is very possible that the error-terms will be associated with these time-invariant variables, which therefore provides a reason for choosing random effects (Kumar and Ahmed, 2015:p. 237).

\subsection{Fixed-Effects Filtered Estimation Method}

Identifying and predicting the effects of time-invariant variables such as race and gender effects that do not change over time is frequently the center of panel regression analysis. However, prediction methods such as fixed effects (FEs), which give highly coherent predictions of the coefficients of independent variables that time-varying, are not used for estimating time-invariant effects because the fixed effects estimation removes all time-invariant independent variables. As a consequence, the prediction of time-invariant effects, namely, how to infer effects that do not change over time without making a clear statement about the relationship among undetected individual effects and variables that change over time, posed a challenge to panel econometrics (Pesaran and Zhou, 2018:p. 1137).

Pesaran and Zhou (2018) reveal a static data panel model that allows for a random association between time variable covariates and individual effects and proposes a fixed-effect filtering (FEF) approach for predicting variable coefficients that do not change over time but vary between cross-sections. In this kind of panel model, $\mathrm{N}$ represents a large cross-sectional dimension while $\mathrm{T}$ 
consists of a small and a constant time dimension. The fixed effect filtering estimation method proposed by Pesaran and Zhou consists of two simple stages. In the first stage, fixed effect estimates are calculated for the coefficients of time varying variables and these predictions are employed to filters time varying effects. In the second stage, the error terms obtained from the first stage panel regression are averaged over time and used as a dependent variable in the crosssectional least square regression containing the intercept and the time-invariant regressor vector. Based on the identifying hypothesis that time-invariant regressors are not associated with individual effects and a variety of other conditions of regularity, it is shown that the FEF predictor is unbiased and consistent for a finite T and as $\mathrm{N} \rightarrow \infty$. Pesaran and Zhou (2018) derived the FEF predictor's asymptotic distribution. They proposed a nonparametric covariance matrix predictor, which was consistent with the heteroscedasticity of the individual effects and worked decently in the existence of residual serial correlation (Pesaran and Zhou, 2018: p. 1138).

Considering the panel model, which contains both time-varying and time-invariant regressors:

$y_{i t}=\alpha_{i}+z_{i}^{\prime} \gamma+x_{i t}^{\prime} \beta+\varepsilon_{i t}, i=1,2, \ldots \ldots N ; t=1,2, \ldots T$ where $\quad \alpha_{i}=\alpha+\eta_{i}$ (6)

$x_{i t}^{\prime}$ is a $\mathrm{k} \times 1$ vector of time-varying variables, and $z_{i}^{\prime}$ is an $\mathrm{mx} 1$ vector of observed individual variables that vary only across the cross-sectional units, $i$. Intercalarily $z_{i}^{\prime}$, the outcomes, $y_{i t}$ are also governed by unobserved individual-specific effects, $\alpha_{i}$. The center of the analysis is on prediction and deduction including the elements of $\gamma$. Obviously, without any more limitations on $\alpha_{i}, \gamma$ cannot be determined even if $\beta$ was known to the researcher (Pesaran and Zhou, 2018:p. 1139).

At this point, the FEF predictor should be figured out by using the following two-stage process: In stage one, by using model (6), figure out the fixed effects estimator of $\beta$, represented by $\hat{\beta}$, and the associated residuals $\hat{u}_{i t}$ defined by

$$
\hat{u}_{i t}=y_{i t}-\hat{\beta}^{\prime} x_{i t}
$$

In stage two, figure out the time averages of these residuals, $\overline{\hat{u}}_{\imath}=T^{-1} \sum_{t=1}^{T} \hat{u}_{i t}$ and regress $\overline{\hat{u}}_{l}$ on $z_{i}$ with an intercept to acquire $\hat{\gamma} F E F$, namely,

$\hat{\gamma} F E F=\left[\sum_{i=1}^{N}\left(z_{i}-\bar{z}\right)\left(z_{i}-\bar{z}\right)^{\prime}\right]^{-1} \sum_{i=1}^{N}\left(z_{i}-\bar{z}\right)\left(\overline{\hat{u}}_{\imath}-\overline{\hat{u}}\right)$

and $\hat{\alpha}_{F E F}=\overline{\hat{u}}-\widehat{\gamma^{\prime}} F E F \bar{z}$, where $\overline{\hat{u}}=N^{-1} \sum_{i=1}^{N} \overline{\hat{u}}_{\mathrm{i}}$. (Pesaran and Zhou, 2018:p. 1140).

This marks the end of the second stage. 


\subsection{Stochastic Frontier Estimation Method}

When the performance of an economic unit is a matter of debate, the concepts of efficiency and productivity come to the forefront. The output-to-input ratio is productivity, and the ratio between potential and observed outputs (or inputs) is efficiency (Fried et.al., 2008:p.6). In spite of the idea that efficiency is as old as neo-classical economics, theoretical works started in 1951 with the studies of Koopmans and Debreu (Koopmans, 1951; Debreu,1951). However, first empirical work started with Farrell in 1957 (Farrell, 1957) on its own calculations. Technical efficiency calculation means comparing the current amounts of the input and output to their potential amounts. All in all, in any field where potential amounts and observed amounts differ, efficiency analysis can be applied. The study carried out in this direction, estimates the efficiency in international trade, based on the hypothesis that the actual trade volume and potential trade volume may differ.

Potential amounts need to be predicted because there are no observable amounts. To realize this prediction procedure and to measure the technical efficiency, some approaches were developed in the literature. The most accepted of these methods are the nonparametric data envelopment analysis and the parametric stochastic frontier analysis (Zhang et. al., 2013: p. 654-655). The Stochastic frontier analysis was proposed by Aigner et al. (1977) and Meeusen and van Den Broeck (1977), independent of each other. Unlike the previous models, there exists the term "random error". Therefore, deviations from the maximum product are not completely ascribed to inefficiency, so the error term here is separated into two pieces as the term ineffectiveness effects and the random error term (Stevenson,1980:p. 57).

Using panel data analysis, the stochastic frontier function can be expressed as follows:

$$
\begin{gathered}
y_{i t}=\beta x_{i t}+v_{i t}-u_{i} \\
v_{i t} \sim \text { i.i.d. } N\left(0, \sigma_{v}^{2}\right) \\
u_{i} \sim \text { i. i.d. } N^{+}\left(\mu, \sigma_{v}^{2}\right)
\end{gathered}
$$

where $\mathrm{x}$ denotes input, and $\mathrm{y}$ denotes output. In the frontier function, the error term is separated into two pieces. The initial one $\left(v_{i t}\right)$ is the random error term that is not under the control of the examined unit and provides that the frontier function is stochastic. The second $\left(u_{i}\right)$ expresses the ineffectiveness effects. As can be understood from the subscript of the term $u$ in the equation, the ineffectiveness effects of the model do not change over time (Aigner et. al., 1977: p. 24). Pitt and Lee (1981) and, Battese and Coelli (1988) are the examples of ineffectiveness models not changing with time. If the timespan taken in the 
calculation of the frontier function is long dated, the presumption that ineffectiveness does not change over time can lead to spurious findings. With time-varying type models, this rigid presumption has been removed. Instances of time-varying ineffectiveness models are Battese and Coelli (1995), Lee and Schmidt (1993), Battese and Coelli (1992), Kumbhakar (1990), and Cornwell et al. (1990). As previously stated, the calculation of technical effectiveness includes comparing the current input and output amounts with their potential amounts. Overall, an analysis of effectiveness can be applied in any field where potential amounts and actual amounts are different.

The stochastic frontier gravity equation can be defined as follows, as indicated by Kalirajan (2008):

$$
X_{i j}=f\left(Z_{i} ; \beta\right) \exp \left(v_{i}-u_{i}\right)
$$

where $X_{i j}$ refers to the export of country $i$ to country $j$, and $Z_{i}$ refers to the determinants of potential trade. The stochastic frontier gravity model is typically calculated using the "maximum likelihood" method. When the model is expressed in logarithmic terms, the ratio of observed to potential trade gives the efficiency level $\left[\exp \left(-u_{i}\right)\right]$ :

$$
\exp \left(-u_{i}\right)=\frac{X_{i j}}{f\left(Z_{i} ; \beta\right)+\exp \left(v_{i}\right)}=\frac{\text { observed } \text { Trade }}{\text { Potential Trade }}
$$

[exp (-ui)] is a number along 0 and 1 . If the number is equal to 0 , this means that the observed trade amount is equal to the potential trade amount, and there is no inefficiency. If this number is $\left[0<\exp \left(-u_{i}\right) \leq 1\right]$, this indicates the presence of inefficiency. In this case, it means that some factors cause exports to remain below the potential level (Kalirajan, 2008:p. 1039). In this paper, the analysis is realized by employing Battase and Coelli's (1988) model, which is timeinvariant, and Battase and Coelli (1995) model, which is time-varying.

\section{DATA SET}

The time span of the data consists of the period 2010-2016. The countries that make up the cross-sectional dimension in the study are divided into two groups. The first is the countries that export energy goods, and the second is the countries that export non-energy goods. In the period 2010-2016, countries whose exports consist of at least $60 \%$ or more of fossil fuels and its derivatives were selected as energy-selling countries. The selected 20 countries are Yemen, Venezuela, United Arab Emirates, Turkmenistan, Russia, Saudi Arabia, Republic of the Congo, Qatar, Oman, Nigeria, Libya, Kazakhstan, Kuwait, Brunei, Gabon, Iran, Iraq, Azerbaijan, Angola, and Algeria.

As for the countries exporting non-energy goods, the major economies of the world have been taken into consideration, especially in the export of manufacturing industry products. Selected countries realized approximately $90 \%$ 
of the manufacturing industry product exports in the world in 2016. These are United States, United Kingdom, Turkey, Thailand, Switzerland, Sweden, Spain, South Korea, Poland, Netherlands, Mexico, Malaysia, Hong Kong, India, Indonesia, Ireland, Italy, Japan, China, Czech Republic, France, Germany, Australia, Austria, Belgium, Brazil, and Canada.

Since the analysis is on bilateral trade between the country selling nonenergy goods and the country selling energy goods, there are 1080 trade directions. In the empirical model, the natural logarithms of variables other than binary variables are taken. The reason for choosing the natural logarithm is that it makes the series flatter, solving the heteroscedasticity problem, and interpreting the results in terms of elasticity. The description and the source of the variables used in the estimations are explained in the following.

In this study, the exports realized from the countries selling energy goods to the countries selling non-energy goods and the export realized in the opposite

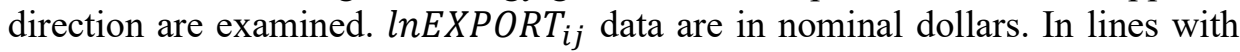
zero trade, 1 is added to the nominal value of zero. This method is applied in gravity models. Data from World Bank, World Integrated Trade Solutions (WITS) and United Nations International Trade Statistics are used.

Gross Domestic Product (GDP) is an important data indicator for the economic powers and market sizes of the countries. Large GDP indicates more production and marketing for the exporter and economic power for the importer to purchase the goods. In theory, the expected signs are positive (Demir, 2019:p. 120). The data are expressed in nominal dollars. $\ln G D P_{i}$ and $\ln G D P_{j}$ are taken from the World Bank, World Development Indicators.

Whether the impact of the population on exports is positive or negative is a controversial issue. This impact depends on whether the absorption impact is greater than the scale impact directly associated with the population. Depend on Greene (2013), countries that have higher populations have more and broader range of productions, are more independent, and prefer to trade less than those with smaller populations. From another point of view, Yang and MartinezZarzoso (2014) reported that the population is negatively related to trade flows, as the large population will have a wider domestic market, rich resource allocation, and different outcomes, and is also less dependent on international specialization. In addition, they also noted that the population coefficient could be positive as a larger population in an importing country. This describes economies of scale and allows countries to trade more with international partners in a wide variety of goods. $\ln P O P_{i}$ and $\ln P O P_{j}$ are taken from World Bank, World Development Indicators. 
The distance variable $\left(\operatorname{lnD} \mathrm{I} S T A N C E_{i j}\right)$ is commonly referred to as trade friction (trade barrier). Therefore, the distance has a negative effect on trade flows from both heuristic and econometric viewpoints. The distance variable is a function of the spatial effect on trade flows. As the distance between the two countries increases, the cost of transportation increases and consequently the trade volume decreases. Thus, according to the theory, the expected sign is negative (Sumani, 2015: p. 53). The relevant data are obtained from CEPII (Centre d'Etudes Prospectives et d'Informations Internationales - Center for Prospective Studies and International Information).

The variable of gross domestic product per capita difference ( $\ln D G D P P C_{i j}$ ) is used to discover which countries fit the Heckscher-Ohlin or Linder hypotheses in world trade. The Heckscher-Ohlin hypothesis foresees that countries where per capita income rates are not same would trade more than countries with same levels. The Linder hypothesis, by contrast, suggests that countries with same per capita income rates should trade more with each other, as they will have same preferences for diversified goods. So, the Linder hypothesis is concerned with the negative impact of the per capita GDP difference between countries $i$ and $j$ on bilateral trade. A positive impact of this variable is related with the Heckscher-Ohlin hypothesis (Sumani, 2015: 53). GDP per capita variables are taken from World Bank, World Development Indicators. The absolute values of the differences of country $i$ and j's GDP per capita variables are taken.

CONTIGUITY $_{i j}$ is the dummy variable added to the model as a common border measure. It implies that countries without common borders will bear more costs in trade. This variable is set as 1 for those who have common boundaries and 0 for those who do not. The data are obtained from CEPII.

The presence of a common language between countries reduces transaction costs during trade. In this case, there are two common-language dummy variables. The common official language variable indicates that the two countries use the same official language, while the common ethnic language variable is the language spoken by at least $9 \%$ of the population in both country $\mathrm{i}$ and country $\mathrm{j}$ (Mayer and Zignago, 2011:p. 12). COMMON OFFICIAL LANGUAGE $_{\mathrm{ij}}$ and COMMON ETHNIC LANGUAGE $\mathrm{ij}_{\mathrm{ij}}$ data are obtained from CEPII.

It is obviously difficult to make a specific definition of a colonial relationship. Here, colonization is a very general concept that ruled the relationship between the two countries, regardless of their degree of growth, and contributed to the current state of their institutions for a long time (Mayer and Zignago, 2011:p. 12). COMCOL is a sign that the two trading countries had a 
common colonialism after 1945. The COLONY variable indicates that there was a colonial connection between the two countries in the past. COL45 indicates that there was a colonial relationship between the two countries after 1945. These data are also obtained from CEPII.

Cost differences between countries in foreign trade are undoubtedly one of the main reasons for foreign trade. Since countries do not have the same price advantage in the production of every good, they import goods that do not have price advantage. Therefore, price formation is important in foreign trade. What is meant by price formation in foreign trade is the formation of international relative prices. In other words, "balance" is the formation of terms of trade (Demir, 2019:p. 122). That's why in this framework, $\ln P$ is the variable that forms the basic argument of the study. This variable is added to the model by predicting the relative price variable $\left(\mathrm{P}_{\text {world }}\right)$, found by dividing the two indices, to give the barter price. The first of these indices is the Energy Price Index (EPI). This index is obtained by looking at the coal, oil, and natural gas export values of developing countries between 2002-2004. These values are based on fixed weighting Laspeyres indices of the data from the World Bank, Global Economy Monitor. These series are available from 1960 to present. This index, with a base value of $2010=100$, has been chosen in terms of energy goods prices. The second index is the Non-Energy Goods Price Index (NEPI). It is the index obtained by looking at the export values of 34 products of developing countries, which are based on the constant weighting based Laspeyres indices of the data taken from the World Bank, Global Economic Monitor. These series are available from 1960 to present. This index, which has a base value of $2010=100$, is selected in order to give nonenergy goods prices. Thus, $\mathrm{P}=\mathrm{EPI} / \mathrm{NEPI}$ is a data that is formed as 1 in 2010.

The index, referred to as the Baltic Dry Index in the literature, is a measure of the shipping price of the main raw materials such as metals, grains and fossil fuels by sea. This index was created by the London Baltic Exchange based on daily assessments in the shipbrokers' panel. In addition to the distance factor stated as transportation costs, the basic reason for obtaining this index is to examine the effect of the change in transportation costs over time, even though the geographical distance factor has not changed over the years. The Baltic index variable is obtained by taking the closing value of that year. A delayed value is added to the empirical model because the costs of the previous year are included in the export value of any year. This data are obtained from the web page of Kitco (www. https://www.kitco.com/commentaries/2016-12-21/The-14-Year-Recordof-the-Baltic-Dry-Index.html). 


\section{EMPIRICAL FINDINGS}

Empirical findings related to the study obtained by random effects, stochastic frontier, and fixed effect filtered estimation methods are given in Table 2 .

Table 2: Comparative Panel Regression Estimation Results

\begin{tabular}{|c|c|c|c|c|}
\hline Dependent Variables & $\begin{array}{c}\text { Random } \\
\text { Effects }\end{array}$ & $\begin{array}{c}\text { Stochastic } \\
\text { Frontier } \\
\text { Analysis } \\
\text { Battase- } \\
\text { Coelli } \\
(1988)\end{array}$ & $\begin{array}{c}\text { Stochastic } \\
\text { Frontier } \\
\text { Analysis } \\
\text { Battase- } \\
\text { Coelli (1995) }\end{array}$ & $\begin{array}{c}\text { Fixed Effect } \\
\text { Filtered } \\
\text { Estimation }\end{array}$ \\
\hline Constant $\left(a_{0}\right)$ & $\begin{array}{l}-34.26974 * \\
(2.409098)\end{array}$ & $\begin{array}{l}-21.27551^{*} \\
(2.163573)\end{array}$ & $\begin{array}{c}-27.22303^{*} \\
(1.31744)\end{array}$ & ---------------- \\
\hline $\ln G D P_{i}$ & $\begin{array}{c}1.675364 * \\
(0.0677464 \\
)\end{array}$ & $\begin{array}{c}1.180706^{*} \\
(0.0708143)\end{array}$ & $\begin{array}{c}1.180706^{*} \\
(0.0708143)\end{array}$ & $\begin{array}{c}1.801606 * \\
(0.2579459) \\
\text { t-value: } 6.98\end{array}$ \\
\hline $\ln G D P_{j}$ & $\begin{array}{c}1.018883 * \\
(0.0677464 \\
)\end{array}$ & $\begin{array}{l}0.9679818^{*} \\
(0.0548508)\end{array}$ & $\begin{array}{l}0.9679818^{*} \\
(0.0548508)\end{array}$ & $\begin{array}{c}0.943495 * \\
(0.1848382) \\
\text { t-value: } 5.10\end{array}$ \\
\hline $\ln P O P_{i}$ & $\begin{array}{c}- \\
0.2836886 \\
* \\
(0.0659222 \\
)\end{array}$ & $\begin{array}{c}-0.1953826^{*} \\
(0.0559163)\end{array}$ & $\begin{array}{c}-0.1953826^{*} \\
(0.0559163)\end{array}$ & $\begin{array}{c}-1.170378 * * \\
(0.6725445) \\
\text { t-value: }-1.74\end{array}$ \\
\hline $\operatorname{lnPOP}$ & $\begin{array}{c}0.2433338 \\
* \\
(0.0659222 \\
)\end{array}$ & $\begin{array}{l}0.2194462^{*} \\
(0.0583534)\end{array}$ & $\begin{array}{l}0.2194462^{*} \\
(0.0583534)\end{array}$ & $\begin{array}{c}2.221958^{*} \\
(0.5450042) \\
\text { t-value: } 4.08\end{array}$ \\
\hline $\operatorname{lnDISTANCE_{ij}}$ & $\begin{array}{c}-1.454534 * \\
(0.1231221 \\
)\end{array}$ & $\begin{array}{l}-1.018775^{*} \\
(0.1205974)\end{array}$ & $\begin{array}{l}-1.018775^{*} \\
(0.1205974)\end{array}$ & $\begin{array}{c}-1.599759 * \\
(0.2670403) \\
\text { t-value:- } 5.99\end{array}$ \\
\hline $\ln P$ & $\begin{array}{c}-3.665815^{*} \\
(0.1342656 \\
)\end{array}$ & $\begin{array}{l}-3.414778^{*} \\
(0.1321227)\end{array}$ & $\begin{array}{l}-4.558542 * \\
(0.2045572)\end{array}$ & $\begin{array}{c}-3.672662 * \\
(0.1917929) \\
\text { t-value: - } \\
19.15\end{array}$ \\
\hline $\ln B A L T I C(t-1)$ & $\begin{array}{l}-0.571338^{*} \\
(0.041869)\end{array}$ & $\begin{array}{l}-0.6034138^{*} \\
(0.0420453)\end{array}$ & $\begin{array}{c}-0.7669682^{*} \\
(0.0610107)\end{array}$ & $\begin{array}{c}-0.5279338^{*} \\
(0.0339701) \\
\text { t-value: - } \\
15.54\end{array}$ \\
\hline
\end{tabular}


KAUJEASF 12(24), 2021: 946-974

\begin{tabular}{|c|c|c|c|c|}
\hline $\ln D G D P P C_{i j}$ & $\begin{array}{c}- \\
0.0883859 \\
* \\
(0.0379097 \\
)\end{array}$ & $\begin{array}{l}-0.1003383^{*} \\
(0.0358484)\end{array}$ & $\begin{array}{l}-0.1607061^{*} \\
(0.0271357)\end{array}$ & $\begin{array}{c}-0.028438 \\
(0.0457542) \\
\text { t-value: }-0.62\end{array}$ \\
\hline CONTIGUITY $_{i j}$ & $\begin{array}{c}0.4947797 \\
(0.5904999 \\
)\end{array}$ & $\begin{array}{l}0.4475561 \\
(0.507605)\end{array}$ & $\begin{array}{c}0.3201121 \\
(0.2638846)\end{array}$ & $\begin{array}{c}-0.5192702 \\
(1.30884) \\
\text { t-value: }-0.40\end{array}$ \\
\hline $\begin{array}{l}\text { COMMON OFFICIAL } \\
\text { LANGUAGE }\end{array}$ & $\begin{array}{c}-0.1731613 \\
(0.5936326 \\
)\end{array}$ & $\begin{array}{l}-0.3969789 \\
(0.5366389)\end{array}$ & $\begin{array}{l}-0.1661203 \\
(0.2686025)\end{array}$ & $\begin{array}{c}-0.5495505 \\
(1.220326) \\
\text { t-value:- }-0.45\end{array}$ \\
\hline $\begin{array}{l}\text { COMMON ETHNIC } \\
\text { LANGUAGE }\end{array}$ & $\begin{array}{c}0.4446814 \\
(0.4949877 \\
)\end{array}$ & $\begin{array}{c}0.322784 \\
(0.4491613)\end{array}$ & $\begin{array}{r}0.3775066^{* *} \\
(0.2220182)\end{array}$ & $\begin{array}{c}0.6982801 \\
(1.069058) \\
\text { t-value: } 0.65\end{array}$ \\
\hline $\operatorname{COLONY}_{i j}$ & $\begin{array}{c}0.7652988 \\
(0.7334084 \\
)\end{array}$ & $\begin{array}{c}0.5838432 \\
(0.5506854)\end{array}$ & $\begin{array}{l}0.8298744^{*} \\
(0.3321252)\end{array}$ & $\begin{array}{c}0.5873516 \\
(1.089948) \\
\text { t-value: } 0.54\end{array}$ \\
\hline $\mathrm{COMCOL}_{i j}$ & $\begin{array}{c}2.025321^{*} \\
(0.3913951 \\
)\end{array}$ & $\begin{array}{l}1.400664 * \\
(0.3233057)\end{array}$ & $\begin{array}{l}1.778922 * \\
(0.1754524)\end{array}$ & $\begin{array}{l}2.217859 * \\
(0.9273259) \\
\text { t-value: } 2.39\end{array}$ \\
\hline$C O L 45_{i j}$ & $\begin{array}{l}0.3851858 \\
(0.908389)\end{array}$ & $\begin{array}{l}0.4045686 \\
(0.7269412)\end{array}$ & $\begin{array}{c}0.2082053 \\
(0.4091852)\end{array}$ & $\begin{array}{c}0.7017701 \\
(1.54038) \\
\text { t-value: } 0.46\end{array}$ \\
\hline \multicolumn{5}{|c|}{ Descriptive Statistics About Models } \\
\hline OBSERVATION & 7560 & 7560 & 7560 & 7560 \\
\hline F-Wald Statistics & 3085.40 & 2546.11 & 7121.95 & \multirow{3}{*}{$\begin{array}{c}\text { T-Statistics } \\
\text { Critical Value } \\
\text { at } \% 5 \text { and } \% \\
10 \text { levels are } \\
1.96 \text { and } 1.65 .\end{array}$} \\
\hline Prob $>\mathrm{F}$ & 0.0000 & 0.0000 & 0.0000 & \\
\hline LOG-LIKELIHOOD & ------- & $-1.679 \mathrm{e}+04$ & $-1.851 \mathrm{e}+04$ & \\
\hline
\end{tabular}

Values between parentheses are standard errors. * Significance level is 5\%. ** Significance level is $10 \%$.

Source: Calculated by authors using the STATA statistics program.

Consequently, considering the findings from the three econometric estimation methods; the gross domestic product and populations of both exporting and importing countries, price (P), distance, Baltic Dry Index and common colonizer variables are all statistically significant and have the same signs in all methods. 
The GDP variable is both significant and positive for exporter and importer. The high GDP for the exporter means that the exporter countries are able to trade more, due to their comparative advantages. For the importer, having a high income means more imports.

The sign of the population of the exporter is negative, and the sign of the population of the importer is positive and significant. As mentioned earlier, there is no consensus in the literature regarding what the sign of the population would be. To have the negative sign of the exporting country's population means that the domestic market of the exporting country does not require internationalization due to its rich resource allocation. The population of the importing country has the positive sign; it means that imported products are effective in competing with domestic products. On the other hand, it indicates that the production level is inadequate due to the high domestic demand.

The estimation results suggest that the distance variable is negative and significant and therefore meet the theoretical expectation. Thus, transportation costs increase, and accordingly trade volume decreases.

The price variable $\mathrm{P}$ is the variable that forms the basic argument of our study. When the percentage change in the energy goods price index is more than the change in non-energy goods, the export elasticity is greater than 1 and negative. Accordingly, considering the elasticity relationship between energy and non-energy goods in the scale of the countries discussed, the reaction of exports to the percentage of change in energy goods prices is negative and more than one. The opposite is also true for the non-energy goods sector. In other words, a $1 \%$ increase in the relative price, expressed as $\mathrm{P}$, would decrease the exports by $3.66 \%$ in Random Effect, $4.45 \%$ in Stochastic Frontier, and 3.67\% in Fixed Effects Filtered Estimation Methods. As a result, the main hypothesis of the study, which suggests that the increase in energy prices will affect exports negatively, is confirmed. In this case, it can be interpreted that the terms of trade would be against the countries exporting non-energy goods.

The Baltic index is a measure of shipping prices. In this study, its effect on the trade is found to be negative and significant. Therefore, as global transportation costs increase, exports decrease.

The last important variable examined belongs to the common colony relationship. Results reveal that countries with common colonists have positive effects on trade.

In this context, policy suggestions for a total of eight variables are discussed in detail in the conclusion section of the article. However, as stated in the literature section, it should be noted that especially Chen and Hsu (2013), Sato and Dechezleprete (2015), and Rafiq, Sgro and Apergis (2016) are the closest 
studies to this subject. Therefore, it is important to compare the findings with the studies in the literature. Our empirical results in the work in hand, confirm Chen and Hsu (2013) in the sense that oil prices adversely affect the trade, the distance variable has negative while the GDP has positive signs. That is, Chen and Hsu (2013) find similar significant results in contiguity and common language, in a different way, insignificant results in population variables. Unlike our study, insignificant results are found in population variables, and significant results are found in contiguity and common languages.

Our study is compatible with the study of Sato and Dechezleprete (2015) in terms of GDP's positive sign, negative distance sign, insignificant contiguity and common official language, and the contraction effect of oil price increases on international trade. Rafiq, Sgro, and Apergis (2016) reveal that the increase in oil prices negatively affects the trade balance of oil-exporting countries. In this context, their results coincide with our study.

In summary, all studies reveal that price increases in energy goods affect trade negatively. In addition, the argument that the two major countries will trade more, becomes stronger with the result of positive GDP sign. The fact that the distance variable is negative and significant confirms the opinion that nearby countries trade more. Whether the common official language and contiguity variables are significant or not depends on the status of the data set. Therefore, the two main variables, namely GDP and distance, are very important in gravity model studies. In this study, these variables are also found to be significant and thus important.

\section{CONCLUSION}

Considering the results for all three estimation methods, namely Panel Random-Effects Estimation, Fixed Effects Filtered, and Stochastic Frontier Estimation Methods, the estimated coefficients of $\mathrm{GDP}_{\mathrm{i}}, \mathrm{GDP}_{\mathrm{j}}, \mathrm{POP}_{\mathrm{i}}, \mathrm{POP}_{\mathrm{j}}$, relative price $(\mathrm{P})$, Baltic, distance, and common colonial (comcol) variables are all robust and consistent in terms of sign and significance.

In this context, it would be suitable to confirm that the countries need to focus on growth-oriented policies in order to increase their trade volume depending on their GDPs. Accordingly, high growth in the global economy causes an increase in international trade. Otherwise, trade may contract.

Our results suggest that the effect of the $\mathrm{POP}_{\mathrm{i}}$ variable which indicates the population of the exporting country on trade is negative; while the effect of the $\mathrm{POP}_{\mathrm{j}}$ variable which shows the population of the importing country on the trade is positive. Hence, the negative effect of the population variable for the exporter can be interpreted as the size of the domestic market and rich resource allocation. 
The fact that the population variable of the importing country is positive enables imported goods to compete better with domestic goods and balances the foreign sales of domestic exporters. This result remarks economies of scale and encourages the country to make more trade with foreign trade partners in a wide variety of products. As a result, the problem arises as to what situation the policy proposal will be made for. According to all the methods used in this study and the findings of the econometric analyses, the effect of the importer's population variable on the trade is robustly greater and more significant as the regression coefficient than the effect of the exporter's population. Therefore, policy recommendations are comfortably made where the population of the importing country positively affects trade. In this framework, economies that consider the opportunities offered by economies of scale would provide a competitive advantage. Hence, countries require effective competition policies. In this context, efficiency should be increased; quality products should be developed with low prices and technological innovations should be made to ensure fair and effective competitive environments.

The common colonizer variable has a positive impact on exports and is significant. Although this variable is a fixed variable coming from the historical duration, it is important in terms of cultural affinity. In this context, countries with cultural ties in the past can continue their ties today and carry them to the next generations, which can increase the exports of countries. Beyond economic cooperation, it is also important that the increasing cultural convergence of countries will increase trade such as education, health, arts, and literature.

Considering both the time-varying Baltic index and the effect of the timeinvariant distance variable, the increase in transportation costs negatively affects trade between countries. In this context, it is obvious that the implementation of effective logistics management methods will have significant improvement effects to produce effective policies reducing world transportation prices.

The relative increase in prices (EPI/NEPI) seems to negatively affect exports, which coincides with many studies in the literature. In this case, it is thought that the policies that can prevent the rise of energy prices, and the coordination of international economic policy, will positively affect the world trade volume. Thus, the artificial demand increase for fossil fuels created by consumers can be reduced. Therefore, clean energy subsidies that would encourage the use of alternative energy sources are recommended to be provided by the public sector to the system. In addition, it is important to create energy conservation awareness that will reduce the overuse of energy resources. Many actors in the economy have a duty to provide energy in a healthy and sustainable manner and to meet demand. At this point, it implies that it would be more 
beneficial for energy producers to invest in renewable energy sources in terms of sustainable ecological balance, since increasing fossil fuel supply causes negative environmental effects to meet the increasing demand.

As known, the transportation sector has the highest energy consumption, and fossil fuels are used in a significant part of this sector. Considering the energy consumption levels, the manufacturing industry is second, and as regards the domestic use in the third, the share of fossil fuels in these areas is considerably high. For this reason, the automotive sector, one of the main energy -consuming sectors, needs to develop hybrid vehicle technologies and even switch to the production of fully electric vehicles.

In addition, infrastructure and vehicle production for public transportation are suggested to be encouraged. It is also proposed that the manufacturing industry sector needs using substitute energy products as inputs in the production process instead of fossil fuels. It is obvious that increasing the use of solar panels and similar environmentally friendly technologies for selfcontained domestic use can reduce the need for fossil fuels. At this point, increasing solar and wind power plants, which are included in the public energy production process, may decrease the demand for fossil fuels.

\section{CONFLICT OF INTEREST STATEMENT}

There is no conflict of interest between the authors.

\section{FINANCIAL SUPPORT}

No funding or support was used in this study

10. AUTHOR CONTRIBUTIONS

MAD, UU: Idea and Design

MAD, UU: Theoretical Framework

MAD: Econometric Methodology

MAD: Data Collection and Processing

MAD: Data Analysis and Interpretation

MAD: Literature Review

MAD, UU: Writing of Article

MAD, UU: Interpretation of Findings

UU: Critical Review of Article

11. ETHICS COMMITTEE STATEMENT AND INTELLECTUAL

\section{PROPERTY COPYRIGHTS}

Ethics committee principles were followed in the study. There has been no situation requiring permission within the framework of intellectual property and copyrights. 


\section{REFERENCES}

Abidin, I. S. Z., Haseeb, M., Azam, M., \& Islam, R. (2015). Foreign direct investment, financial development, international trade and energy consumption: Panel data evidence from selected ASEAN countries. International Journal of Energy Economics and Policy, 5(3), 841-850.

Abu Bader, S., \& Abu Qarn, A. S. (2010). Trade liberalization or oil shocks: Which better explains structural breaks in international trade ratios?. Review of International Economics, 18(2), 250-264.

Aigner, D., Lovell, C.A.K., \& Schmidt, P. (1977). Formulation and estimation of stochastic frontier production functions. Journal of Econometrics, 6(1), 21-37.

Akman, E., \& Bozkurt, I. (2016). On the mixed indirect effects of oil prices on international trade. OPEC Energy Review, 40(4), 374-396.

Allegret, J. P., Mignon, V., \& Sallenave, A. (2015). Oil price shocks and global imbalances: Lessons from a model with trade and financial interdependencies. Economic Modelling, 49, 232-247.

Allen, T., \& Arkolakis C. (2016). Elements of advanced international trade. 10 Ekim 2017 tarihinde http://www.econ.yale.edu/ ka265/teaching/GradTrade/notes/ClassNotes.pdf adresinden erişildi.

Anderson, J. E., \& Van Wincoop, E. (2003). Gravity with gravitas: A solution to the border puzzle. American Economic Review, 93(1), 170-192.

Anna, C., Antonello, D., \& Angelo, P. (2014). A panel data approach to evaluate the passenger satisfaction of a public transport service. Procedia Economics and Finance, 17, 231-237.

Backus, D. K., \& Crucini, M. J. (2000). Oil prices and the terms of trade. Journal of International Economics, 50(1), 185-213.

Battese, G. E.,\& Coelli, T. J. (1988). Prediction of firm-level technical efficiencies with a generalized frontier production function and panel data. Journal of Econometrics, 38(3), 387-399.

Battese, G.E., \& Coelli, T. J. (1992). Frontier production functions, technical efficiency and panel data: With application to paddy farmers in India. The Journal of Productivity Analysis, 3(1), 153-169.

Battese, G.E., \& Coelli, T. J. (1995). A model for technical inefficiency effects in a stochastic frontier production function for panel data. Empirical Economics, 20(1), 325-332.

Bergstrand, J. H. (1989). The generalized gravity equation, monopolistic competition, and the factor-proportions theory in international trade. The Review of Economics and Statistics, 71(1), 143-153.

Bergstrand, J. H., Egger, P., \& Larch, M. (2013). Gravity redux: Estimation of gravityequation coefficients, elasticities of substitution, and general equilibrium comparative statics under asymmetric bilateral trade costs. Journal of International Economics, 89(1), 110-121. 
Bridgman, B. (2008). Energy prices and the expansion of world trade. Review of Economic Dynamics, 11(4), 904-916.

Chan, H. R., Manderson, E., \& Zhang, F. (2017). Energy prices and international trade: Incorporating input-output linkages. 10 Ocak 2018 tarihinde http://documents.worldbank.org/curated/en/984751496166477456/pdf/WPS80 76.pdf adresinden erişildi.

Chen, S. S., \& Hsu, K. W. (2013). Oil price volatility and bilateral trade. The Energy Journal, 34(1), 207-229.

Cornwell, C., Schmidt, P., \& Sickles, R. C. (1990). Production frontiers with crosssectional and time-series variation in efficiency levels. Journal of Econometric, 46(1-2), 185-200.

Debreu, G. (1951). The coefficient of resource utilization. Econometrica, 19(3), 273-292.

Demir, M.A. (2019). Uluslararası enerji fiyatlarının dünya ticareti üzerine etkisi. Yayınlanmamış doktora tezi, Dokuz Eylül Üniversitesi, İzmir.

Farrell, M. J. (1957). The measurement of productive efficiency. Journal of the Royal Statistical Society. Series A (General), 120(3), 253-290.

Fried, H. O., Lovell, C. K., Schmidt, S. S., \& Schmidt, S. S. (2008). The measurement of productive efficiency and productivity growth. USA: Oxford University Press.

Greene, W.H. (2008). Econometric analysis. USA: Pearson.

Greene, W. (2013). Export potential for US advanced technology goods to India using a gravity model approach. US International Trade Commission, Working Paper, (2013-03B), 1- 43.

Huntington, H. G. (2015). Crude oil trade and current account deficits. Energy Economics, 50, 70-79.

Kalirajan, K. (2008). Gravity model specification and estimation: Revisited. Applied Economics Letters, 15(13), 1037-1039.

Kilian, L., Rebucci, A., \& Spatafora, N. (2009). Oil shocks and external balances. Journal of International Economics, 77(2), 181-194.

Koopmans, T. C. (1951). An analysis of production as an efficient combination of activities. T.C. Koopmans (Ed). in Activity analysis of production and allocation (pp. 33-97). NewYork: John Wiley\&Sons.

Kumar, S., \& Ahmed, S. (2015). Gravity model by panel data approach: An empirical application with implications for South Asian countries. Foreign Trade Review, 50(4), 233249.

Kumbhakar, S. C. (1990). Production frontiers, panel data, and time-varying technical inefficiency. Journal of Econometrics, 46(1-2), 201-211.

Lee, Y. H., \& Schmidt, P. (1993). A production frontier model with flexible temporal variation in technical efficiency. Harold O. Fried, C.A. Knox Lovell \&Shelton S. Schmidt. (Eds.). in The measurement of productive efficiency: techniques and applications (pp. 237-255). NewYork: Oxford University Press.

Lutz, C., \& Meyer, B. (2009). Economic impacts of higher oil and gas prices: The role of international trade for Germany. Energy Economics, 31(6), 882-887. 
Mayer, T., \& Zignago, S. (2011). Notes on CEPII's distances measures: The geodist database. $\quad 15 \quad$ Ocak $2018 \quad$ tarihinde http://www.cepii.fr/PDF_PUB/wp/2011/wp2011-25.pdf adresinden erişildi.

Meeusen, W., \& van Den Broeck, J. (1977). Efficiency estimation from cobb douglas production functions with composed error. International Economic Review, 18(2), 435-444.

Pesaran, M. H., \& Zhou, Q. (2018). Estimation of time-invariant effects in static panel data models. Econometric Reviews, 37(10), 1137-1171.

Pitt, M., \& Lee, L. F. (1981). The measurement and sources of technical inefficiency in the Indonesian weaving industry. Journal of Development Economics, 9(1), 43 64.

Rafiq, S., Sgro, P., \& Apergis, N. (2016). Asymmetric oil shocks and external balances of major oil exporting and importing countries. Energy Economics, 56, 42- 50.

Raheem, I. D. (2017). Asymmetry and break effects of oil price-macroeconomic fundamentals dynamics: The trade effect channel. The Journal of Economic Asymmetries, 16, 12-25.

Sato, M., \& Dechezleprêtre, A. (2015). Asymmetric industrial energy prices and international trade. Energy Economics, 52(1), 130-141.

Starck, S. C. (2012). The theoretical foundation of gravity modelling: What are the developments that have brought gravity modelling to mainstream economics. Unpublished master dissertation, Copenhagen Business School Department of Economics, Copenhagen.

Stevenson, R. E. (1980). Likelihood functions for generalized stochastic frontier estimation. Journal of Econometrics, 13(1), 57-66.

Sumani, I.I. (2015). Determinants of Ghana's trade flows in economic community of West African States: Application of the gravity model. Unpublished master dissertation. İstanbul Technical University, İstanbul.

Szewerniak, W., Xu, Y., \& Dall'erba, S. (2016). The effects of oil price on regional trade in the United States. 10 Ekim 2017 tarihinde https://papers.ssrn.com/sol3/papers.cfm?abstract_id=2863943 adresinden erişildi.

Timilsina, G. R. (2015). Oil prices and the global economy: A general equilibrium analysis. Energy Economics, 49, 669-675.

Welsch, H. (2008). Armington elasticities for energy policy modeling: Evidence from four European countries. Energy Economics, 30(5), 2252-2264.

Wooldridge, J.M. (2016) Introductory Econometrics A Modern Approach. USA:Cengage.

Yang, S. and Martinez-Zarzoso, I. (2014). A Panel Data Analysis of Trade Creation and Trade Diversion Effects: The case of ASEAN-China Free Trade Area. China Economic Review. 29: 138-151. 
Zhang, N., Zhou, P. and Choi, Y. (2013). Energy efficiency, CO2 Emission Performance and Technology Gaps in Fossil Fuel Electricity Generation in Korea: A metafrontier Non-Radial Directional Distance Function Analysis. Energy Policy. 56: 653-662.

Zhao, X., Li, T., \& Zhai, D. (2016). Effects of oil price volatility on bilateral trade between China and the GCC. L. Lester (Ed). in Energy relations and policy making in Asia (pp. 11- 30). Singapore: Palgrave Macmillan.

Appendix1: Studies that Indirectly Examine the Relationship between Energy Price and World Trade

\begin{tabular}{|c|c|c|c|c|}
\hline $\begin{array}{l}\text { Researchers } \\
\text { and } \\
\text { Year of } \\
\text { Research } \\
\end{array}$ & Sample & Method & $\begin{array}{ll}\text { Reason } & \text { for } \\
\text { Research } & \end{array}$ & Main Finding \\
\hline $\begin{array}{l}\text { Backus and } \\
\text { Crucini } \\
(2000)\end{array}$ & $\begin{array}{l}\text { Developed } 8 \\
\text { countries for the } \\
\text { period } 1955- \\
1990 .\end{array}$ & $\begin{array}{l}\text { Dynamic general } \\
\text { equilibrium } \\
\text { model }\end{array}$ & $\begin{array}{l}\text { The effect of oil } \\
\text { shocks on the } \\
\text { general balance } \\
\text { of the economy. }\end{array}$ & $\begin{array}{l}\text { In terms of } \\
\text { foreign trade, } \\
\text { there is a } \\
\text { negative } \\
\text { relationship } \\
\text { with oil prices } \\
\text { outside of } \\
\text { Canada. }\end{array}$ \\
\hline $\begin{array}{l}\text { Bridgman } \\
(2008)\end{array}$ & $\begin{array}{l}\text { United States of } \\
\text { America - } \\
\text { Canada water } \\
\text { transportation } \\
\text { data for the proxy } \\
\text { of transportation } \\
\text { costs } \\
\text { 1960-2005 } \\
\text { period. }\end{array}$ & $\begin{array}{l}\text { Computable } \\
\text { general } \\
\text { equilibrium } \\
\text { model }\end{array}$ & $\begin{array}{l}\text { In this study, } \\
\text { tariffs, energy } \\
\text { prices, and the } \\
\text { vertical } \\
\text { specialization } \\
\text { trade model in the } \\
\text { energy-using } \\
\text { transportation } \\
\text { sector within the } \\
\text { framework of } \\
\text { these energy } \\
\text { prices are } \\
\text { examined. }\end{array}$ & $\begin{array}{l}\text { They stated that } \\
\text { oil shocks } \\
\text { increase } \\
\text { transportation } \\
\text { costs and offset } \\
\text { the falling tariff } \\
\text { rates, so it is not } \\
\text { necessary to } \\
\text { change the } \\
\text { price-import } \\
\text { elasticity. }\end{array}$ \\
\hline $\begin{array}{l}\text { Welsch } \\
(2008)\end{array}$ & $\begin{array}{l}\text { In } 4 \text { European } \\
\text { countries } \\
\text { Germany, France, } \\
\text { Italy, United } \\
\text { Kingdom } \\
15 \text { goods groups. } \\
\text { 1979-1990 } \\
\text { period. }\end{array}$ & $\begin{array}{ll}\text { Armington } & \\
\text { elasticities } & \text { and } \\
\text { Johansen } & \text { co- } \\
\text { integration } & \end{array}$ & $\begin{array}{l}\text { The elasticity of } \\
\text { goods as } 60 \\
\text { country- } \\
\text { commodity } \\
\text { groups were } \\
\text { calculated and } \\
\text { modeled with } \\
\text { time series. Here, } \\
\text { it is aimed to find } \\
\text { out which goods }\end{array}$ & $\begin{array}{l}\text { It has been } \\
\text { observed that } \\
\text { elasticity is high } \\
\text { in the machinery } \\
\text { industry, but it is } \\
\text { stated as a } \\
\text { policy proposal } \\
\text { that energy } \\
\text { regulations } \\
\text { affect these }\end{array}$ \\
\hline
\end{tabular}




\begin{tabular}{|c|c|c|c|c|}
\hline & & & $\begin{array}{l}\text { have superiority } \\
\text { based on their } \\
\text { elasticity values. }\end{array}$ & $\begin{array}{l}\text { values } \\
\text { general. }\end{array}$ \\
\hline $\begin{array}{ll}\text { Lutz and } \\
\text { Meyer } \\
(2009)\end{array}$ & $\begin{array}{l}\text { Trade values of } 25 \\
\text { goods and } 1 \\
\text { service sector for } \\
\text { a single country } \\
\text { (Germany), } \\
\text { GDP, Export } \\
\text { Ratio, Disposable } \\
\text { income, and the } \\
\text { price index for } 50 \\
\text { countries (Opec } \\
\text { and Others) } \\
\text { The simulations } \\
\text { start in } 2007 \text { and } \\
\text { make predictions } \\
\text { for } 2010 \text { and } \\
2020 \text {. }\end{array}$ & $\begin{array}{l}\text { Extensive and } \\
\text { disaggregated } \\
\text { global } \\
\text { GINFORS } \\
\text { (global inter- } \\
\text { industry } \\
\text { forecasting } \\
\text { System) model } \\
\text { and the detailed } \\
\text { INFORGE } \\
\text { (inter-industry } \\
\text { forecasting } \\
\text { Germany) model } \\
\text { for the German } \\
\text { economy. These } \\
\text { models are based } \\
\text { on input-output } \\
\text { analysis. }\end{array}$ & $\begin{array}{l}\text { In this study, it } \\
\text { was studied } \\
\text { whether a } \\
\text { permanent oil } \\
\text { price increase has } \\
\text { a stabilizing } \\
\text { effect on } \\
\text { international } \\
\text { trade and the } \\
\text { economy of an } \\
\text { oil-importing } \\
\text { country through } \\
\text { an internal } \\
\text { structural change } \\
\text { on GDP. }\end{array}$ & $\begin{array}{l}\text { From the } \\
\text { perspective of } \\
\text { Germany, it is } \\
\text { seen that there is } \\
\text { a shift from the } \\
\text { consumer goods } \\
\text { sector to the } \\
\text { investment } \\
\text { goods sector, } \\
\text { and Germany's } \\
\text { international } \\
\text { competitive } \\
\text { advantage has } \\
\text { limited the } \\
\text { negative impact } \\
\text { of rising energy } \\
\text { prices. }\end{array}$ \\
\hline $\begin{array}{l}\text { Kilian, } \\
\text { Rebucci and } \\
\text { Spatafora } \\
(2009)\end{array}$ & $\begin{array}{l}\text { Oil trade balance, } \\
\text { non-oil trade } \\
\text { balance, current } \\
\text { account, capital } \\
\text { gains, and } \\
\text { changes in net } \\
\text { foreign assets of } \\
\text { the Oil Exporting } \\
\text { Countries and the } \\
\text { USA, Japan, Euro } \\
\text { Area for the } \\
\text { period 1970- } \\
\text { 2005. }\end{array}$ & $\begin{array}{l}\text { Structural VAR } \\
\text { (vector } \\
\text { autoregressive) } \\
\text { model }\end{array}$ & $\begin{array}{l}\text { The aim of the } \\
\text { study is to } \\
\text { examine the } \\
\text { effects of supply } \\
\text { and demand } \\
\text { shocks in global } \\
\text { crude oil markets } \\
\text { on external } \\
\text { balances in the } \\
\text { economy. }\end{array}$ & $\begin{array}{l}\text { The effect of oil } \\
\text { demand and } \\
\text { supply shocks } \\
\text { on the trade } \\
\text { balance of oil- } \\
\text { exporting and } \\
\text { oil-importing } \\
\text { countries also } \\
\text { depends on the } \\
\text { effect of the } \\
\text { non-oil trade } \\
\text { balance. }\end{array}$ \\
\hline $\begin{array}{lr}\begin{array}{l}\text { Abu- } \\
\text { and }\end{array} \text { Bader } \\
\text { Qarn }(2010)\end{array}$ & $\begin{array}{l}\text { Import/GDP and } \\
\text { Export/GDP for } \\
\text { the 1957-1993 } \\
\text { period of } 55 \\
\text { countries }\end{array}$ & $\begin{array}{l}\text { Time Series } \\
\text { (Vogelgang and } \\
\text { Bai-Perron } \\
\text { Structural Break } \\
\text { Tests) }\end{array}$ & $\begin{array}{l}\text { It has been stated } \\
\text { that structural } \\
\text { refractions in } \\
\text { trade ratios occur } \\
\text { with oil shocks } \\
\text { rather than trade } \\
\text { liberalization } \\
\text { periods. }\end{array}$ & $\begin{array}{l}\text { Most of the } \\
\text { structural breaks } \\
\text { in trade ratios in } \\
55 \quad \text { countries } \\
\text { occurred during } \\
\text { the } 1973 / 1974 \\
\text { and } 1979 / 1980 \\
\text { oil shocks. }\end{array}$ \\
\hline $\begin{array}{l}\text { Huntington } \\
\text { (2015) }\end{array}$ & $\begin{array}{l}\text { Current account } \\
\text { deficit as a } \\
\text { dependent } \\
\text { variable } \\
91 \text { countries for } \\
1984-2009\end{array}$ & $\begin{array}{l}\text { Panel fixed- } \\
\text { effect model. }\end{array}$ & $\begin{array}{l}\text { A discussion has } \\
\text { been made on } \\
\text { how reducing oil } \\
\text { import } \\
\text { dependency can } \\
\text { reduce a country's }\end{array}$ & $\begin{array}{l}\text { Net oil exports } \\
\text { create a current } \\
\text { account surplus, } \\
\text { while net oil } \\
\text { imports do not }\end{array}$ \\
\hline
\end{tabular}


KAUJEASF 12(24), 2021: 946-974

\begin{tabular}{|c|c|c|c|c|}
\hline & & & $\begin{array}{ll}\text { trade } & \text { deficit } \\
\text { under } & \text { certain } \\
\text { conditions. }\end{array}$ & $\begin{array}{l}\text { affect current } \\
\text { account deficits. }\end{array}$ \\
\hline $\begin{array}{l}\text { Allegret, } \\
\text { Mignon and } \\
\text { Sallenave } \\
(2015)\end{array}$ & $\begin{array}{l}\begin{array}{l}\text { GDP, } \\
\text { price, }\end{array} \\
\text { account bulrent } \\
\text { exchange rate, oil } \\
\text { price, oil } \\
\text { production value } \\
\text { of } 30 \text { countries for } \\
\text { the period 1980- } \\
2011\end{array}$ & $\begin{array}{ll}\text { Global } & \text { VAR } \\
\text { model } & \end{array}$ & $\begin{array}{l}\text { To investigate the } \\
\text { effects of oil price } \\
\text { shocks and to } \\
\text { examine their } \\
\text { relationship with } \\
\text { transmission } \\
\text { channels on } \\
\text { global } \\
\text { imbalances. }\end{array}$ & $\begin{array}{l}\text { Due to the } \\
\text { nature of } \\
\text { demand or } \\
\text { supply shocks, } \\
\text { the impact of oil } \\
\text { price shocks on } \\
\text { international } \\
\text { imbalances is } \\
\text { normal. }\end{array}$ \\
\hline $\begin{array}{l}\text { Timilsina } \\
\text { (2015) }\end{array}$ & \begin{tabular}{lr} 
GDP & \multicolumn{2}{r}{ sectoral } \\
trade for & 27 \\
sectors in 25 \\
countries/regions \\
The scenarios are \\
implemented \\
starting from \\
2012.
\end{tabular} & $\begin{array}{l}\text { Computable } \\
\text { general } \\
\text { equilibrium } \\
\text { model }\end{array}$ & $\begin{array}{l}\text { Examine the } \\
\text { impact of } \\
\text { projected oil price } \\
\text { increases on the } \\
\text { global economy } \\
\text { as well as specific } \\
\text { regional/national } \\
\text { economies. }\end{array}$ & $\begin{array}{l}\text { Especially in } \\
\text { terms of the } \\
\text { effect of the } \\
\text { study } \\
\text { international } \\
\text { trade, it was } \\
\text { seen that MENA } \\
\text { increased its } \\
\text { trade, high- } \\
\text { income } \\
\text { countries were } \\
\text { not affected } \\
\text { much, and their } \\
\text { middle incomes } \\
\text { were affected. }\end{array}$ \\
\hline $\begin{array}{l}\text { Abidin, } \\
\text { Haseeb, } \\
\text { Azam and } \\
\text { Islam (2015) }\end{array}$ & $\begin{array}{l}\text { Indonesia, } \\
\text { Malaysia, } \\
\text { Philippines, } \\
\text { Singapore, } \\
\text { Thailand for the } \\
\text { period 2005-2013 }\end{array}$ & $\begin{array}{ll}\text { Panel data } \\
\text { evidence } \\
\text { (Causality) }\end{array}$ & $\begin{array}{l}\text { Causality } \\
\text { between energy } \\
\text { consumption and } \\
\text { FDI and financial } \\
\text { development and } \\
\text { trade }\end{array}$ & $\begin{array}{l}\text { There is } \\
\text { bidirectional } \\
\text { causality } \\
\text { between trade } \\
\text { and energy } \\
\text { consumption. } \\
\end{array}$ \\
\hline $\begin{array}{l}\text { Akman and } \\
\text { Bozkurt } \\
(2016)\end{array}$ & $\begin{array}{l}10 \text { oil exporting } \\
\text { countries and } \\
\text { their main trading } \\
\text { partners for the } \\
\text { period } 1950-2013\end{array}$ & VAR & $\begin{array}{l}\text { To investigate the } \\
\text { indirect effect of } \\
\text { oil prices on the } \\
\text { trade of oil- } \\
\text { exporting } \\
\text { countries and } \\
\text { their partners. }\end{array}$ & $\begin{array}{l}\text { Imports of many } \\
\text { oil-exporting } \\
\text { countries are } \\
\text { negatively } \\
\text { affected by the } \\
\text { indirect effect of } \\
\text { oil prices. }\end{array}$ \\
\hline $\begin{array}{l}\text { Zhao, Li and } \\
\text { Zhai (2016) }\end{array}$ & $\begin{array}{l}\text { China and } 6 \text { gulf } \\
\text { countries for the } \\
\text { period 1994-2014 }\end{array}$ & $\begin{array}{l}\text { Panel GMM } \\
\text { (general methods } \\
\text { of moments) } \\
\text { Model }\end{array}$ & $\begin{array}{l}\text { It examines the } \\
\text { effect of oil price } \\
\text { volatility on } \\
\text { China's trade with } \\
6 \text { Gulf countries. }\end{array}$ & $\begin{array}{l}\text { Different types } \\
\text { of oil price } \\
\text { shocks have } \\
\text { different effects } \\
\text { on China-Gulf } \\
\text { trade. }\end{array}$ \\
\hline
\end{tabular}




\begin{tabular}{|c|c|c|c|c|}
\hline $\begin{array}{l}\text { Szewerniak, } \\
\text { Xu and } \\
\text { Dall'erba } \\
(2016)\end{array}$ & $\begin{array}{lrr}\text { US } & \text { States } & \text { for } \\
2002, & 2007, & \text { and } \\
2012 & & \end{array}$ & $\begin{array}{l}\text { PPML (poisson } \\
\text { pseudo- } \\
\text { maximum- } \\
\text { likelihood) panel } \\
\text { Ordinary least } \\
\text { squares panel }\end{array}$ & $\begin{array}{l}\text { It is to examine } \\
\text { the effect of } \\
\text { diesel prices on } \\
\text { the trade between } \\
\text { the states of the } \\
\text { USA. }\end{array}$ & $\begin{array}{l}\text { The increase in } \\
\text { diesel prices } \\
\text { reduces the } \\
\text { volume of trade. }\end{array}$ \\
\hline $\begin{array}{l}\text { Chan, } \\
\text { Mandersson } \\
\text { and Zhang } \\
(2017)\end{array}$ & $\begin{array}{l}\text { Energy and trade } \\
\text { data for } 43 \\
\text { countries and } 10 \\
\text { manufacturing } \\
\text { industry sectors } \\
\text { for the period } \\
1991-2012\end{array}$ & $\begin{array}{l}\text { Input-output } \\
\text { PPML panel }\end{array}$ & $\begin{array}{ll}\text { The effect } & \text { of } \\
\text { energy costs in } \\
\text { production } & \text { on } \\
\text { export } & \\
\text { performance } & \\
\text { examined. } & \end{array}$ & $\begin{array}{l}\text { Energy costs } \\
\text { have a strong } \\
\text { impact on } \\
\text { exports. }\end{array}$ \\
\hline $\begin{array}{l}\text { Raheem } \\
(2017)\end{array}$ & $\begin{array}{l}\text { China, Germany, } \\
\text { USA, India, } \\
\text { Russia and } \\
\text { Canada for the } \\
\text { period January } \\
1992 \text { to June } 2016\end{array}$ & $\begin{array}{l}\text { ARDL } \\
\text { (Autoregressive } \\
\text { distributed lag) } \\
\text { Model } \\
\text { NARDL (Non- } \\
\text { linear ARDL) } \\
\text { Model } \\
\text { Bai-Perron } \\
\text { structural break } \\
\text { test }\end{array}$ & $\begin{array}{l}\text { It is to examine } \\
\text { the country-based } \\
\text { effects of oil price } \\
\text { changes } \\
\text { exports, imports } \\
\text { and trade } \\
\text { openness. }\end{array}$ & $\begin{array}{l}\text { Exports of oil } \\
\text { prices } \\
\text { Germany and } \\
\text { China, which } \\
\text { have high trade } \\
\text { volumes in the } \\
\text { long-term, the } \\
\text { long-term } \\
\text { imports of } \\
\text { Russia and } \\
\text { Canada, and the } \\
\text { short-term } \\
\text { imports of the } \\
\text { USA and India } \\
\text { asymmetrically } \\
\text { affected. }\end{array}$ \\
\hline
\end{tabular}

Source: Prepared by Authors. 